\title{
SANTERÍA COPRESENCE AND THE MAKING OF AFRICAN DIASPORA BODIES
}

\section{AISHA BELISO-DE JESÚS \\ Harvard University}

"My saints are wherever I go," Obá Bi, an initiated priest of Santería ${ }^{1}$ (AfroCuban Orisha diaspora religious practices) living in New York City told me in 2006. "They [the saints] are here," he said touching the crown of his head. Obá Bi envisioned his saints (Orisha) as part of his body. ${ }^{2}$ He described how the initiation ritual, making santo (also making Ocha), "seats" the Orisha on the crown of practitioners' heads. In Santería, priests' bodies are described ritually as being "made Lucumi" (a term used for enslaved Yoruba in colonial Cuba) through a seating (asiento) process, which entails two spiritual "birthing" (pariendo) ceremonies. Priests first wash and sanctify the Orisha, a combination of sacred stones (otá) and cowry shells (dillogún), and then wash and sanctify the new initiate (iyawó/omó). ${ }^{3}$ These two new sets of beings, Orisha and iyawó, are then joined in the seating, where the sanctified Orisha are placed on the iyawós ritually shaved and painted head (ori). Obá Bi told me that the painting unification is spiritually permanent; it "can never be erased." Each initiation in Santería is a culmination of interarticulated bodily gestures; Orisha and iyawó are cleansed, shaved, fed, and other ritual acts establish mutual living-ness. Practitioners, regardless of race, gender, ethnicity, sexuality, or national affiliation, are thus remade into Yoruba-diaspora religious bodies; they are made Lucumí. ${ }^{4}$

Obá Bi described the heavy weight his arms had to bear during initiation rituals. "I almost can't stand it. My arms tremble." As a godparent, he must 
physically place the Orisha in a soup tureen or cauldron directly on the new Lucumí's head. Initiation rituals require complex religious skills that reference slavery and African-inspired ways of knowing the world. For instance, when discussing the butchering of animals, Obá Bi told me, "It's about precision. . . . When we open [butcher] the four-leggeds [animals], it's in the traditional way. The animals are saving our lives." He then placed his hand around his neck demonstrating how a noose was once put around the necks of slaves as they were hung from trees. "We cut the meat for the collar [necklace/noose] so that we won't be hung like the slaves. It's about being Lucumí. . . . And as we eat the meat, it heals our pains. It makes us whole when most of us are not." The butchering and consuming of the ritually sacrificed animals is understood to ward off this terrible fate. Obá Bi, a light-skinned man of mixed black American and Puerto Rican descent, described how embodied actions of being and becoming Lucumí are linked to forms of racial consciousness. "It's a blessing for black folks to know themselves in this way, and know where we came from and who we are.”

The Orisha (divinities), various spirits, and familial ancestors are recognized as being on, around, and within practitioners' bodies. They are sensed and felt on the body. I call these multiple energies, copresences. Obá Bi and other priests walk with copresences, talking to them and placing them on each other's bodies even as they are understood to manifest through spiritual possessions and trance. Copresences emerged historically in enslaved black people's pragmatic everyday negotiations with Cuban colonialism and racial violence. They embody the physical endurance of black enslaved Africans in the Americas under colonialism and imperialism, as well as contemporary forms of racial feeling and marginalization. Spirits and Orisha engage in warfare; these copresences liberate those enslaved in problematic situations and infiltrate enemies. The agency of the spirits of the dead and of Orisha is thus directly linked to racial-spiritual works (trabajos). Copresences and the everyday rituals that engage them mean to bring balance to otherwise turbulent lives. With their capacity for action, or agency, copresences reflect a form of embodied spiritual habitus. Habitus, according to Saba Mahmood (2005, 136-39), involves the pedagogical practices in which people cultivate a specific conception of self. ${ }^{5}$ A spiritual habitus, I suggest, highlights the self-forming capacities for action enabled through the somatic practices and spiritual relationships practitioners engage in with copresences. In this article, I explore a specific racialhistorical matrix from which these spirits, Orisha, and ancestors emerge as copresences in Matanzas, Cuba. I argue that these self-forming capacities involve 
the coming together of multiple spiritual and material beings in order to make practitioners into African diaspora bodies.

Scholars of African diaspora religions have documented the strategic ontologies that have emerged within histories of racial violence, slavery, colonialism, and imperialism (Brandon 1997; Brown 2003; de la Torre 2004; Palmié 1995; Routon 2008, 2010), and they have referenced these flows of power and resistance within transnational and diasporic projects of reconciliation and recuperation (Clarke 2004; Johnson 2002; Olupona and Rey 2008; Mann and Bay 2001; Matory 2005). African-inspired (Ochoa 2010) diasporas have been conceptualized as relations rather than as a (singular) condition (see Brown 2005), and more recently, diaspora has been conceived historically as a feeling (Guridy 2009). Yet these discussions of diaspora have elided how embodied sensings of copresences might transform the very conception of being from within particular racial schemas (see Matory 2009). ${ }^{6}$

For instance, African and African diaspora spirituality has for the most part continued to be examined through theories of transcendence and notions of mediation (Engelke 2010; van de Port 2006). Media, broadly conceived to include anything from incense, books, cassette tapes, or a person's body (Meyer 2009), are understood to partake in a transcendental (i.e., religious) negotiation between a divine "Other place" and an earthly "here" (Mazzarella 2004). Yet recent debates challenge the Christian presumptions that underlie mediation (Hirschkind 2011; Engelke 2011). They have argued that mediation's transcendentalism hails a universalizing imperialism. Talal Asad (in Derrida 2001, 70) ${ }^{7}$ and Charles Hirschkind (2011) have shown, for instance, how within Islamic practices, the Koran should not be envisioned as a mediator - rather, it is touched, cared for, recited, and thus requires a broader notion of religious experience. These scholars argue for theories of practice instead of mediation.

Yet these conversations have inadvertently reified a presumed opposition between Christian transcendence and Islamic practice. The discussion also plays into what Martin Holbraad (2008) has shown to be an ethnographic locus of negation, the presumed falseness of our anthropological subjects. Indeed, anthropological modes of conceptualizing presence have elided "alternative," "divergent," multiple, or "non-Abrahamic" ontologies of presence (see Matory 2009), and in doing so, they do not take seriously the constitutive body logics and worlds produced through these ontologies. ${ }^{8}$ People like Obá Bi situate the Orisha as part of their body. Orisha, ancestors, and other spirits are not mediated through a heavenly distance between self and divine Other, but rather are experienced as 
intimate copresences of practitioners' sensory modalities, feelings, and bodies. A constitutive principal of mediation as anthropological reasoning cannot see the work that Orisha as body do to practitioners' worlds.

In the following, I first examine the historical renderings of slavery as fields of power for contemporary practitioners. I suggest that copresences must be situated within a racial-historical matrix (Fanon 1967) that shifts conceptions and sensing of being. Second, I argue that practitioners' everyday acts with copresences redefine the capacities of and for action, constructing a spiritual habitus. The various rituals, works, and spiritual acts in Santería thus culminate in a different form of bodily engagement with the world, operating in racial space. Finally, drawing on Frantz Fanon's (1967) notion of racial corporeal schema, I show how copresences produce alternative ontologies, conceptions of racial-spiritual being. I argue that Santería's sensing of copresences refocuses anthropological readings of diaspora.

\section{SPIRITUAL DEFENSES}

In 2005, Inéz, a Venezuelan practitioner living in the United States, had to undergo a lengthy series of ritual cleansings in Cuba, because she had inadvertently picked up a dead African slave who was causing havoc in her life. The malevolent spirit was sent to her sexual partner by an enemy, and because of their proximity (sleeping in the same bed), the spirit had instead latched onto her. In this instance, the "plane of immanence" that "turn[s] out bodies and senses" of the dead as identified by Todd R. Ochoa (2007, 490, 484), could only be resolved by intervention from the agency of the Orisha. Inez had to become Lucumí to get rid of the spirit. Divination rituals diagnosed that the only way to stop the spiritual warfare was for Inez to become a priestess of Santería. During the consultation she was told, "You need a tribe. You need a Black African spirit to stand up for you. And Changó [a warrior Orisha] will defend you."

Many practitioners I spoke with were drawn to Afro-Cuban religions as a result of spiritual twistings (trastornos) in which spirits of the dead caused them grief. Depending on the type of twisting, different spiritual-physical strategies are employed to heal both the multiple spirits and the body of the practitioner. Copresences simultaneously provide evidence of their existence (Holbraad 2008) and are fed, paid honors, treated as a person, and form constitutive parts of bodies. Copresences form part of practitioners' sixth sense (Guerts 2003), that is, their kinesthetic experiences of being-in-the-world. Practitioners in Santería describe chills, shivers, tingles, premonitions, and possessions of the multiple ancestors, 
spirits, elements of nature, and ritual items as "felt" (los siento), as bodily presences. These hybrid material-immaterial "agents of association" (Ochoa 2007) operate on, in, and as the body. Indeed, as noted by Thomas Csordas (1999), embodied epistemologies might be understood to make worlds. Sensing in Orisha diasporas might allow us to rethink ontological questions of being-in-the-world (MerleauPonty 1964; Csordas 1999). ${ }^{9}$

\section{COLONIAL BODIES: Dominated . . . But Not Slaves}

"Ma Monserrate was young when she came but she was already rayada [cut] and fundada [sworn] from over there [Africa]," Alfredo Calvo Cano, a now deceased priest of Aganyu in Matanzas, Cuba, told me in $2006 .{ }^{10}$ He made cutting signs on his cheeks to show where she had been marked. "She was a judge in the land of Egwardo [Egbado]. . . . When she came, she came drumming the Egwardo drum." Pointing with his hand, showing it was from way back, from Africa, he said, "from over there in a canoe, she tried twice, but the canoe wouldn't hold, so they got on a boat. Those old boats that used to exist. They drummed so that everyone would make it. So then that was how they were able to get here.”

"She came as a slave?," I asked.

“Ma Monserrate was not a slave!” Shaking his head emphatically and waving his hand, "And Ma Fermina [his godmother] was not a slave." Clarifying that Ma Monserrate had come to Cuba of her own choosing, Padrino Alfredo said that the first time she tried to leave Africa she was unsuccessful. "She tried in a canoe." It took another try before she could find a ship, and this time she brought the Egwardo drums with her. According to Padrino Alfredo, Ma Monserrate's drumming proved that she had not been a slave; she came to Cuba for prosperity and development. "Ma Monserrate was already pregnant with Ma Florentina in her belly, and when she got to this land she gave birth." Then he stopped for a moment and continued: "Ma Florentina Gonzalez [Monserrate's daughter] was my mother's grandmother." 11 Padrino Alfredo explained, "Which makes me the great-great-grandson of Ma Monserrate.”

Puzzled, I pushed him. "You mean to tell me that a single, pregnant, black African woman traveled first by canoe and then on a ship from Africa to Cuba with her drums and she wasn't a slave?" Shaking his head, he responded: "By the time they got here, everyone was liberated." He clarified, shaking his finger back and forth, "But Ma Monserrate was not a slave. You know, she was dominated by masters, but she was not a slave." 
Monserrate Ápoto Gonzalez (whose religious name was “Obbatero”), like other African-born priestesses in the latter part of the nineteenth century in Cuba, formed part of a reconfiguration of space, time, and body. Through making bodies African (Lucumí), she and many others managed to consolidate a form of embodied racial ontology. Postures and gestures of cutting, shaving, drinking, bending, and swearing - links with fundamentos (copresences) carried or made on their bodies - form part of contemporary Santería's spiritual habitus.

Between 1820 and 1920, a core group of priestesses and priests entered Cuba with significant ritual knowledge that transformed local Lucumí practice and ethos (Mason 1996, 17). Stephan Palmié (2013,43) notes how a commercialized "proto-ethnology," driven by the slave trade in Cuba, created a puzzling ad hoc where as many as 137 variations of the qualifier Lucumí have been documented: "lucumí egba, lucumí egguadó, lucumí iechá, lucumí ifá, or lucumí eyó" to name a few. We know that Ma Monserrate was one of the priestesses from the Egba (also, Egbado) who brought both the Orisha Olókun and Olókun's drums with her from Africa to Matanzas. Armando Ferrer Castro and Mayda Acosta Alegre (2006, 26-27) place the arrival of Egbado to Cuba around 1830, when they were forced to flee their townships due to war in Africa and began a southward migration toward the Ogún River, where many faced enslavement. Ma Monserrate, known as Ápoto, or the "first to reign," was a priestess of Changó who, in the 1830s, began the Cabildo Egwardo on Daoiz Street between Compostela and America Streets in Matanzas (Ferrer Castro and Acosta Alegre 2006, 35; Barrington Edmonds and Gonzalez 2010, 99). The legacy of this period ripples through contemporary copresences - somatic transformations of power and nature.

Fermina Gómez Pastrana, who has been described as "the most illustrious and venerated Santera in Cuba" (Canizares [1993] 2002, 18), was initiated right before the turn of the century. She was born María Pilar Gómez Pastrana in Alacranes in the province of Matanzas on October 12, 1844, during the period known as La Escalera, when colonial fears of a slave rebellion provoked mass torture, racial genocide, and the expelling of black Matanceros to Africa (Ferrer Castro and Acosta Alegre 2006, 64-65). It is said that Ño José Kudaasi, ${ }^{12}$ a priest of Ochún, initially made Fermina to Ochún, even though she was a daughter of Yemayá. Some say that during the initiation, when they sang to Yemayá, that Orisha mounted her and they were forced to reverse (virar el oro) the initiation from Ochún to Yemayá (Mason 1996, 26). Other stories claim that they actually completed the ceremony, but that within her first year "she became twisted" (se 
trastornó), referring to a mental, physical, and spiritual break. Fermina sought help from Ma Monserrate, who corrected Fermina's somatic transformation and named her "Ocha Bi," translated as either "Orisha is born" (Mason 1996, 26) or "Orisha alive." ${ }^{13}$ In either instance, Fermina is the most famous case of a reversing of the Lucumí initiation process and a key element in the transformation of making Lucumí bodies in Cuban Santería.

Through ritual decisions and complex manipulations in the process of making santo, Fermina transformed secret initiations in Matanzas. She is famous for several ritual moves, including continuing rare initiations such as Aganyú and Babaluayé, "directly to the head" (Ferrer Castro and Acosta Alegre 2006, 64). Interviews with elders who lived during Fermina's time make clear that she sought to activate the sensory modes of being-in-the-world through an African-inspired epistemology that reframed the terrors of lived racial trauma. She is said to have established a complex modality of rituals that united ancestral spirits, the Orisha, and deceased slave-warriors in practitioners' bodies in order to heal the spiritual twistings that she and others had experienced. Osvaldo Cárdenas Villamil, a priest in Matanzas, noted that it was Fermina Gómez who first began doing full-seating initiations in the 1940s (Velez 2000, 8-9). ${ }^{14}$

The Egwardo lineage in Matanzas is famous for continuing the worship of the Orisha Olókun, whom Fermina saw as key to calming the spiritual turmoil that blackened bodies had experienced in, through, and as a result of slavery. The story goes that in an effort to calm the instability and racial violence of the time, Ma Fermina created an interpretive transformation of Santería, which allowed non-initiates (aleyos) to receive Olókun. All of the Olókuns on the island are thus considered born from Fermina Gómez's pot. In 1944, Fermina began the tradition of feeding Olókun directly at the ocean, which Padrino Alfredo described as part of "giving the souls who died at sea," and the Orisha who "had to swallow" them, a form of temporary appeasement (Ferrer Castro and Acosta Alegre 2006, 64). "It won't ever be enough," Alfredo told me, "because their suffering is too great. . . . And it is still something that comes and wretches us. . . It can only give them a small reprieve." The spiritual hauntings of unappeased spirits and the ocean forced to swallow the bitter taste of blackened bodies thus form part of an intimate somatic register of social trauma, and of the interarticulated mechanisms of working in and through these frames.

It is important to note that while the histories of Afro-Cuban religions show a multiplicity of African ethnic backgrounds (for instance Egba, Fón/Dahomey, Congo, etc.), Yoruba hegemony is crucial to the ways that bodies are conceived 
of as Lucumí. Drawing on the historical trastornos that emerge in these religious practices, we must note that the move toward a Yoruba-centric sense of blackness as a source of power does not completely reject other forms of blackness, which also arise and twist bodies through their copresences. For instance, Fermina Gómez serves as an example of how a priest might be made erroneously to the wrong Orisha. The bodily practice of these spiritual acts thus has a profound impact on people's ontologies. Twistings show how the relationship with these copresences constitutes cautious and precise techniques of the body. Indeed, as Marcel Mauss ([1935] 1992, 461) identified, "There is no technique and no transmission in the absence of tradition." Embodied traditions of Santería develop active capacities for the impact of copresences on people's bodies. Indeed, copresences' capacities of and for action suggest a specific form of racial-ethnic spiritual habitus. $^{15}$

According to Saba Mahmood $(2005,139)$, the ethical considerations of habitus show how specific conceptions of self (and I would add here, in the case of Santería, copresences), "require different kinds of bodily capacities.” For instance, like Ma Monserrate, a female consecrator of heads (oriaté), Fermina Gómez initiated priests, made bodies Lucumí, during a period of extreme racial repression and open hostility to African-inspired religiosities. Contemporary twistings, such as those reflected by Inéz, who could only relieve her spiritual turmoil by becoming Lucumí, demonstrate an intimate relationship to colonial racial histories such as those twistings encountered by Fermina Gómez. As we shall see, copresences actively challenge, redirect, and at times lay claim to and reenact the historical violences out of which they emerged. "[B]odily form does not simply express the social structure," as Mahmood $(2005,139)$ suggests, "but also endows the self with particular capacities through which the subject comes to enact the world." The bodily capacities enabled by copresences, I argue, can be seen as a form of spiritual habitus.

\section{GRINDING BODIES AND TENSED MUSCLES}

George Brandon (1997, 49; emphasis added) describes the christening rituals of new sugar plantations in nineteenth-century Cuba: "After praying and sprinkling holy water on the machinery, the priest uttered the benediction most appropriate to the occasion: 'In the name of God, go on and prosper.' . . . The planter and his family, friends, and relatives went away to rejoice and feed themselves. Meanwhile the slaves continued what the godfather had begun, grinding and grinding." Santería emerged within this colonial system maintained through violence, re- 
pression, and racial ordering, as well as through its countertechnologies of rebellion, sabotage, secret religions, and other resistance (Brandon 1997; Herskovits 1941; Johnson 2002; Ortiz 1987; Routon 2010). The grinding of sugar production mirrors the grinding of bodies in slavery and the birthing rituals of making Lucumí bodies. Grinding techniques and Catholic benedictions are similarly used to make practitioners' bodies into Lucumí with the expectation that they, like the sugar mill, might "go on and prosper." Depending on lineage, either a mortar or stone is used by the godparents to grind herbs into aché, the sacred substance used for the spiritual birthing process. During the ceremony for the priests' ancestors (Oro Egun), godparents will sprinkle holy water and perfume on the assembled and recite the Our Father and Hail Mary prayers. Then, practitioners enter the ritual room (cuarto de santo) and begin making the sacred waters used to bathe and birth the new initiate and the Orisha by tearing up herbs with their hands. Songs are sung in Lucumí as herbs are torn. Hunched-over priests collectively rip herbs for the different Orisha. This constitutes only a small part of the ritual work of the body.

As has been noted, secrecy has played a key role not only in slavery subversion but also in the embodied technologies of African-inspired religions that emerged from this racial recollection (Brown 2003; Clark 2007; Miller 2009; Otero 2010). Palmié (2002, 181) has described the use of sorcery to counter the "witchcraft" of slavery (see also Otero 2010, 134). The threat of rebellion caused the episode of La Escalera in 1844, a horrific inquisition during which the Spanish authorities tied people to ladders as a form of torture to extract information and find members plotting to overthrow slavery in Matanzas. ${ }^{16}$ Today, small wooden and metal ladders are given to Orisha to prevent practitioners from being "stepped on," "climbed over," "tied up," or have religious power (aché) stolen.

In Matanzas in 1844, Cumpuzano Mandinga, the "Great Sorcerer of Matanzas," made "a small fortune" by selling "all sorts of magic devices" such as "protective amulets" for the liberation movement (Barcia 2008, 45). Today, these same types of amulets continue to be used and are tied to practitioners' waists, on belts, necklaces, or bracelets to keep away death and negativity. Secrecy remains crucial for practitioners. Complex hierarchies of initiation keep those not committed to the Orisha way of life at the periphery of certain practices. White sheets, hung from doors in ritual rooms, block the view of the uninitiated. Yordanka, an uninitiated woman in her early twenties from a large house of Santería in Havana, told me of her frustration at being excluded, while others, particularly foreigners with money but with less knowledge of the religion than her, gained 
access into exclusive ritual spaces. "These whites have no clue, but they have money," Yordanka told me. Referring to the foreigners as both "white" and "Yankee" (Yuma), Yordanka believed her lack of resources made it difficult for her to access a religion that she felt was "in her blood."

In an interesting parallel, Simone, an African American from Oakland, California, told me how "whites," "Central Americans," or "Latinos" thought they had more access to Santería because they spoke Spanish. Talking about a possession in which an Orisha mounted a black Cuban and spoke Spanish, she told me: "They [Latinos/white Central Americans] try and translate for us and look down at [black Americans] like this religion belongs more to them because they speak Spanish. I was like, the Orisha should speak Lucumí, not Spanish. If it's a real Orisha, it should speak Lucumí!" The racial politics of authenticity, religious access, and secrecy form a crucial aspect of conceptualizing Santería as a black practice, but also as Lucumí. As we have seen, Lucumí is a complex and puzzling "proto-ethnology," as described by Palmié (2013); it is a language, an ethnic identification, and an initiate. In the transnational practice of Santería, practitioners from diverse racial, ethnic, and social backgrounds lay claim but also disavow these notions of authenticity in their religious-spiritual habitus. For instance, while Obá Bi and I watched a video of a drum ritual (tambor) in New York City, he marveled at the bodily movements of black Cubans, telling me, "We just can't move like that. Even the Puerto Ricans can't get the African down like the AfroCubans."

Body logics and somatic rituals were used during liberation movements to maintain secrecy among conspirators (Fernandez-Olmos and Paravasini-Gebert 1997; Miller 2009). Even as slaves were coded with Africanized-colonial ethnicities, they also self-organized within cabildos de nación (African ethnic associations) modeled after Spanish Catholic cofradías (guilds) or mutual-aid groups (Moliner Castañeda 2002; Brandon 1997, 73). Lucumí cabildos in particular were structured along the lines of African body epistemologies such as the awo, secret hierarchical societies that included initiations and "oath taking" (Otero 2010, 16). For instance, in a deposition recorded after the discovery of La Escalera, José Gangá recounted the rituals he underwent to join the cause: "After drawing a cross on the ground with a knife, [they] swore loyalty to God and the Virgin Mary . . . he and the other initiated slaves had their hair cut short along their right ears" (Barcia 2008, 42). In contemporary Santería initiations the shaving of the head makes for a particularly important element. Yet during the early years of the Cuban Revolution, many practitioners told me that they could not fully 
shave their heads for fear of being discovered as Santería priests. The corona or crown shaving emerged as a result, in which only a small circle at the top of the head was shaved while the rest of the hair was left intact. One black Cuban woman, an elder priestess in Matanzas who had been a member of the Young Communist Party, told me that for her initiation in the early 1980s she had a corona shave, and could only complete three instead of the seven days of seclusion. She told me, "My corona was just fine. In slavery they couldn't do the whole white thing, or have their head shaved if they were a woman, so this whole fanaticism with having to shave it all or you're not a true Lucumí is just fanaticism. That's what it is: fanaticism."

With the abolition of slavery in 1887 and the formation of the new republic, cabildos were driven underground by authorities (Brandon 1997, 72; de la Fuente 2001, 161; Paquette 1952, 62, 78). The paraphernalia of African-inspired religious practices were hidden in plain sight in practitioners' homes: in pots, closets, and cabinets, under beds, and in secret altar rooms - much as they are today. Shrines and permanent altars were hidden and clandestine initiation ceremonies became the rule of Ocha (la regla de Ocha). Afro-Cuban religions emerged through ritual postures and gestures based pragmatically on navigating the layered fields of racially embodied violence and repression. Making bodies Lucumí enabled a religious setting in which proving trust, dedication, and loyalty was a matter of life (arikú) and death (ikú), of "showing face" (cara/courage) and "having heart" (okán/truth). Much of this depended on establishing the true nature (iwapele) of new adherents through divination, embodied demonstrations of commitment, and a reliance on somatic attunement with African-inspired copresences (Clark 2007, $21,146)$.

\section{COPRESENCES: Attending to Bodies}

Ontology — once it is finally admitted as leaving existence by the waysidedoes not permit us to understand the being of the black man. For not only must the black man be black; he must be black in relation to the white man. Some critics will take it on themselves to remind us that this proposition has a converse. I say that this is false. The black man has no ontological resistance in the eyes of the white man. Over night the Negro has been given two frames of reference within which he has had to place himself. His metaphysics, or, less pretentiously, his customs and the sources on which 
they were based, were wiped out because they were in conflict with a civilization that he did not know and that imposed itself on him.

-Frantz Fanon, Black Skin, White Masks

Addressing abjection and opposition, racial phenomenologists of the body and postcolonial theorists have leaned on Fanon's corporal schema in Black Skin, White Masks (1967) to reflect on lived experiences of the colonized (Khalfa 2008; Noland 2009; Scott 2010). Fanon posits the blackness of the blackened body as an alienated pathological consciousness that is always opaque, never revealed to (him)self, and must therefore be transgressed. Yet whereas some scholars interpret Fanonian existentialism as a gesture toward the need to open a "third space" (Kipfer 2007), I follow those who walk with Fanon's embodied experience (Scott 2010). In one of the most powerful moves in Black Skin, White Masks, Fanon (1967, 89) describes being "blackened" when a white child on a train sees him and cries out: "Look, a Negro!" Fanon explodes, crying involuntarily. In that moment, the body, what he calls the "lived experience of a Black man," is kinesthetically experienced. ${ }^{17}$ Carrie Noland $(2009$, 205) suggests that when we first come into contact with Fanon's sob, it is his body that insists, demands, that we witness it. Fanon's gesture "argues from the body" from which he is compelled to throw himself à corps perdu, "headlong into action (or creation)" (Khalfa 2005, 47). Indeed, Fanon describes the feeling of being blackened as "tensed muscles," in which the body registers what the mind might not fully comprehend (Scott 2010). Barnor Hesse (1997, 82; emphasis in the original) finds potential in Fanon's somatic action-creation — the possibility for racially experienced diasporic reversals. Hesse describes the potential of black diaspora ontology: "It initiates . . . it turns subordination into insubordination and constitutes a series of tactical disruptions which expose an ethical precariousness in the racialised governance of western culture; it creates, that is, the space of interrogation."

An anthropology of the body and the senses is helpful in decentering particular forms of Cartesian consciousness by shifting elemental awareness and attending to bodies as the primary locus of experience (Bendix 2005; Brenneis 2005; Csordas 1999, 2009; Diaconu 2002, 2006; Guerts 2003; Hirschkind 2006; Howes 1990, 2003; Jackson 1983, 1989; Jobs and Mackenthun 2011; Lingis 2005; Mauss [1935] 1992; Seremetakis 1993; Sklar 1994; Stoller 1984; van Ede 2009). Because senses are culturally encoded (Guerts 2003), we can pay ethnographic attention to the somatic modes that encompass not only one's own way of attending to and experiencing the body but also the "embodied presence of others" (Csordas 1999, 
138). As Csordas $(1999,149)$ suggests, it is important to not simply reproduce the false distinction between bodies and "culture," but instead explore with bodies. Rather than aiming to fill a discursive gap between cognition and embodiment, I suggest that Santería copresences allow us to walk with embodied ontologies (Sheets-Johnston 1999; Noland 2009).

I follow the moves of scholars who invoke Fanon through his tears and tensed muscles (Noland 2009, 204; Scott 2010). In situating phenomenological racial somatics as a framework in anthropology, we might open up glimpses into specific loci of racialized, gendered, and sexed embodied spatial temporalities. To be clear, my interest in this approach is not to posit Santería solely as a liberatory experience or as an exemplary site of decolonization, nor even as pure resistance, but to examine the attempts (whether successful or incomplete) to constitute embodied subjecthood in the very nexus of abject power that Fanon decried, which is then felt and sensed diasporically by different religious subjects. The initiations that Hesse suggests thus constitute key elements in psychic-somatic relations from which African-inspired practices emerge as countercolonial sites of modernity (Palmié 2002). It is in these racial ontological pragmatics that religious diasporas are sensed.

Conjure, for a moment, the slave-referenced ontologies of grinding sugar, whipping bodies, drowning souls, plowing fields, and the kinesthetic spontaneity of movement in Santería rituals. African-inspired blackened racial corporeal schemas are part of the historical memory-making of people's affective registers. Santería epistemologies offer a site to examine the ways in which racial diasporas are felt. Moving in historical racial-spaces, Santería and other African-inspired practices find their racialized and sexualized power of embodied self-awareness precisely in the experience of extravagant black abjection (Scott 2010). This awareness creates detours that reroute trauma to reach a place where (even if only for a glimmer) blackness is recovered and bodies are made Lucumí through an embodied racial sensitivity. This form of corporeal schema indeed constitutes a habitus, a combined set of ritual practices and praxis that assert racial sensitivity. Thus, whereas Fanon lamented black subjects' loss of agency, that is, colonial subjects' inability to access sensorimotor awareness, we can perhaps imagine sites where embodied racial memory initiates embodied capacities of and for action. Feeling copresences in Santería is ritualized and practiced, a spiritual habitus that asserts the capacities of blackened agency. Nevertheless this assertion of racial sensitivity is not always limited to black subjects - and becomes extremely complicated when hailings of black embodiment conflict with racial religious hierar- 
chies. For instance, the examples of Yordanka and Simone above demonstrate that racial corporealities are often out of place on nonblack bodies. Fanon (1967, 116) refers to this as being "overdetermined from without." Phenomenologically, he revises Hegel's formula of sense certainty to show how racial ontologies form a "certain uncertainty." That is, where his body knows the world through habits, what Fanon (1967, 110-11; emphasis in the original) describes as "a slow composition of my self as a body in the middle of a spatial and temporal world - such seems to be the schema." In exploring the penetrating ontology of Cuban Palo spirits of the dead, Ochoa (2007) similarly draws on the philosophical unfoldings of Hegelian being to show instead how sense un-certainty lingers in the immediacy and connection of sense experience. He looks at immanence and bodily intimacy with spirits of the dead as a way "to posit a kind of knowing that is outside of negation/penetration mediation, a knowing outside of the dialectic" (Ochoa 2007, 487). I bring together Fanon's certain uncertainty, the racial corporeal schema in a specific blackened habitus, and Ochoa's sense uncertainty, the forceful sensations and moments of knowing spirits, to understand Santería's lingering and forceful relations in the notion of copresences. Copresences are intimately sensed as beings - agents of racial-corporeal schemas that attune bodies through a habitus of slavery, imperialism, and colonialism as historical-cultural matrixes. While blackness emerges as multiple, uncertain, and not necessarily celebrated in these schemas, blackened immanence is indeed a presence. I argue that blackness cannot be removed from Santería copresences' formations of body worlds.

Santería's body schema emerges from within a complex racial-historical matrix that must be situated within specific ontologies of violence, power, and religious inspiration. I suggest that the process of making Lucumí bodies creates particular forms of somatic registering. It is a mode of sensing diaspora - a way of being in and knowing the world emerging within specific racialized and gendered body memory (Daniel 2005). The historical spatio-temporal-racial encodings, themselves initiated in the transatlantic commerce in bodies, are thus crucial to how Santería copresences are sensed by differently situated practitioners (Bordo 1998; Bourdieu 1990; Csordas 2011; Howes 2003; Mascia-Lees 2011; Taussig 1993).

\section{SPIRIT AGENCY: Foldings}

Santería's spiritual habitus encourages us to fold temporal spatialities. The material elements_ _ otá and dillogún of Orisha diasporas — have been described as "external organs" of practitioners' bodies (Sansi-Roca 2005) and as affecting 
presences (Armstrong 1981). They encompass a broad range of material-immaterial beings and can be thought of as active spiritual and religious subjectivities intimately tied to practitioners' bodily registers. Once an initiate is "crowned" (coronado), the priest's spirit space multiplies into different bodily spheres. While alive, this connective spirit-energy (ayalá) sits in the back of the neck at the base of the skull (monokú eledá), and the Orisha enters through the crown and lives in the head organ (ori). Inspired by French Kardecian spiritism, Santería cosmologies fold soul energies as multiple and united simultaneously and can be hailed through bodily tingles and sensory reactions to spiritual-environmental fields (Clark 2007, 89; Cros Sandoval 2008, 365; Fontañez 2006, 269). Priests' spirit souls are diffracted as they journey to obtain constant and always expanding forms of enlightenment (luz) and development (desenvolvimiento), while they are also in "the dark" (la oscuridad) through their encounters with the difficulties and contaminations of life, dangers, and negative spirits and people (Cros Sandoval 2008; Feraudy Espino 2002). These ontologies fold body and spirit.

Ritually, the moyuba (invocations of the dead) ensure the continued acknowledgment of Egun (ancestor) copresences. The dead contain agency and influence. As J. Lorand Matory (2009, 250) noted more broadly, in Yoruba diasporas "each person's body, set of vessel altars, and sacred paraphernalia thus embody the accumulating presence of a dozen or more gods, spirits of the non-kin dead, and ancestors who have been materially represented, nourished, and ritually inserted in or tied to the body of the priest." In death, portions of priests' spirits remain among the living, while they are also incorporated into Olorun, the rays of light from the sun. Egun are also fused with Orisha; they reside in the natural elements - oceans, rivers, mountains, crossroads, and so forth - even as they are embodied copresences that walk with and often inhabit the bodies of the living (Atwood-Mason 2002; Bolívar-Aróstegui 1990; Cabrera 1968; Falola and Genova 2005; Murphy 1994). In the past, when possible, the bodies of deceased priests were buried in the house compound (ilé de Ocha); now their bodies exist in photographs placed in specific locations (bovedas) in the home. Tables, corners, glasses of water, baskets, and other marked sites are established through complex spiritual communications that discern the placement needs of each copresence. Egun are consulted, offer advice, eat, see, perceive, and, like the Orisha, provide "definitive evidence" (pruebas) of their existence (Holbraad 2008). They differ from the "unenlightened" energies of the death matrix, Ikú, which consist of spirits that are not "uplifted" but nevertheless must be appeased and reckoned with. Egun 
are especially crucial in keeping death, negativities, and other unenlightened spirits away from practitioner's body worlds (Murphy and Sanford 2001, 112).

These sensoriums stimulate senses and sensibilities through divinatory and embodied gazes (miradas). Copresences are not always positive - they can be demanding, jealous, petty, or spiteful and require complex social-spiritual manipulations. Managing the everyday interpersonal logistics of copresences therefore constitutes an integral aspect of Santería's spiritual habitus. An unhappy, distraught, or twisted copresence (from wherever it may come) can mean sickness, death, destruction, tragedy, or misfortune. Thus deals, swindles, bets, and bargaining also take place with copresences alongside the veneration.

Priests I spoke with discussed body logics on different levels of consciousness. While not all practitioners are "horses" (caballos) or "mounters" (subidores), who are possessed by spiritual agents, they are nevertheless in constant states of bodily negotiation with different copresences. They must pay attention to the embodied signs that indicate copresences' warnings or dissatisfaction. Shivers, hair standing on one's arms, feelings, voices, mental pictures, and dreams, as well as divination and trance-based communications, constitute the numerous sensory paradigms that priests register daily. In a dramatic rendition of bodily negotiations, Belkis, a priestess of Changó, discussed her experience of becoming mounted as alternating between moments of distress, nausea, and exhilaration. If she fought the Orisha, she said, "it was almost painful," making her feel like she "would vomit"; otherwise, if she let go, she was filled with "warmth and exhilaration" before she lost consciousness. Yet the body experiences different copresences variously. For example, when describing being mounted by her Egun, Belkis said it felt "like falling asleep." While when she is mounted by her Palo Congo, she is "violently flung around."

Santeros walk through the world negotiating with and being closely related to various spiritual assemblages, and they are constantly concerned about interactions and transactions with diverse copresences in, on, and around the body. Indeed, these embodied ontologies enable Santeros to draw from diverse forms of practice, worship, and different systems of belief as they engage with various energies and beings as copresences. Palmié $(2010,89)$ references the seeming oddity of Santería energetic diversity:

And what about all the statues of Catholic saints, Buddhas, Indians, Dr. Gregorio Hernándezes, or Masonic implements in the shrines of our interlocutors? What of Kardec's Oraciones escogidas flowers and water on a shelf 
in their living room, the nganga power objects they keep hidden in a shed in the backyard, the Spanish translations of the Egyptian Book of the Dead, Nostradamus's prophecies, or Reiki manuals that we might find on their bookshelves, or the abakuá handshake that some of them might offer to a male ethnographer? Is all of this Santería? Where does it begin or end?

I suggest that an embodied epistemology of copresence enables unifications through sensing diaspora. Multiple heterogeneous cosmologies are incorporated within copresence body logics, and reordered as part of Santería's sixth sense (Guerts 2003). For example, the twisted bodies of Fermina Gómez's drowned spirits living with Olókun at the depths of the sea might need attention and erupt like Fanon's tears. These somatic epistemologies unite and initiate bodies, activating relations of embodied consciousness. Neither an ending nor a beginning, death is a kinesthetic continuum of shifting sensory elements.

\section{CONCLUSION: Santería's Sixth Sense}

Just as the agency of "rocks and shells" (Sansi-Roca 2005), protected from the public and hidden in sacred receptacles, disables gazes, their agency also gestures toward diaspora body logics - forms of sensing diaspora. The inherited legacy of copresence enables practitioners to draw from and incorporate diverse formations within racial somatic kinesthetics. However, sensing, knowing the world through the body, is often ignored as a profound element of epistemology. The ways bodies intuit are themselves sociocultural registers (Desjarlais 1992; Guerts 2003; Thomas and Ahmed 2004) and can be described as their sixth sense (Guerts 2003, 3; Noland 2009, 9-10). Copresences manifest as a form of sixth sense, and animate practitioners' bodies. Since sensory experience produces worlds, each form of bodily register constitutes a form of world-making. Santería diasporic sensing is thus an embodied historical editing, an alignment of collective habituated experiences that draw on revivifications of dominance and violence in somatic-spiritual power. Thus in the grinding and cultivating wherein bodies were made and remade black, racialized bodies collapse time and initiate through kinesthetic expression. Copresence punctures cognition, transposing pragmatic resolutions of everyday violences, pleasures, and spontaneous happenings of life.

In these kinesthetic movements Santeros and copresences discover themselves as alive (Sheets-Johnstone 1999, 135). The making of Lucumí bodies is thus an acknowledgment of the historical memory-in-our-own-cells, that is, how muscle tension, pain, despair, suffering, domination, and pleasure are tightly 
bound with postures of perception and consciousness. In conjuring Fanon's copresence I situate Santería as an inspiration to explore the ways in which "the powers of blackness" (Scott 2010, 39) are phenomenologically harnessed. In this sense, then, Santería is about working with, rather than transcending copresence. Whereas Ato Sekyi-Otu (1997, 76) discusses Fanon's concept of imperialist time as an "eviscerated organ of the social body that demands to be resurrected," Santería copresences are kinesthetic extended organs of bodies made Lucumí. In the making of Lucumí bodies, tensed muscles of embodied racial space are loosened and flexed, even if only tenuously. Historical sobs might be released, streaming out and down the face; they eventuate. In the somatic registers of Santería, even Fanon's sobs might be rendered copresences and at least momentarily appeased.

\begin{abstract}
In Santería priesthoods, practitioners are "made" into African diaspora bodies in what is called "making santo." These embodied epistemologies reveal not only the complex historical practices that have emerged through processes of racialization and enslavement but also how a body logic resituates the formations of diasporic feeling and sensing. I argue that practitioners' everyday acts redefine the capacities of and for action as part of a spiritual habitus. The various rituals, works, and spiritual acts in Santería thus culminate in a different form of bodily engagement with the world, operating in racial space. This article examines Santería body logics, showing how what I call copresences are activated in somatic racial ontologies. I suggest that these diasporic sensings resituate anthropological universalisms, arguing for a disruption in the debate between mediation and practice in the anthropology of religion. Rather than assuming notions of presence, copresence allows for an intervention that hails Santería's embodied epistemology as a form of diasporic sensing. [race; Santería; habitus; embodiment; religion; Cuba; United States]
\end{abstract}

\title{
NOTES
}

Acknowledgments This article is based on field research conducted between 2004 and 2011 with Santería practitioners in Matanzas and Havana, Cuba, and in New York City, Miami, Los Angeles, and the San Francisco Bay area. I use pseudonyms for priests who requested confidentiality. This essay forms part of a larger study on the relationship between Cuban and U.S.-based priests examining issues of race, gender, and sexuality from a transnational anthropological approach. I would like to thank Alfredo Calvo Cano and his family in Matanzas, Cuba, for their contributions to my research. I am grateful to Obá Bi and the many priests I interviewed. An earlier version of this article was presented at the Yale University Anthropology Department Colloquium, where generous feedback was provided. My heartfelt thanks go to Kamari M. Clarke, John Jackson, Jr., Sean Brotherton, Jafari S. Allen, Amy Hollywood, Solimar Otero, Naomi Bragin, Brad Erickson, and two anonymous reviewers for their careful readings of the manuscript. I am especially grateful to the editors of Cultural Anthropology for their useful suggestions. 
1. Also, la regla de Ocha, "the rule of Ocha."

2. The Orisha are also called Ocha or Santos.

3. Omó is a "child" of the Orisha. New initiates are also called iyawó (or yawó), the bride of the Orisha. I refer here to the term omó because even uninitiated (aleyo) practitioners learn their embodied familial relations with Orisha first, as omó, "children of the saints" (hijos de santo) (Brown 2003).

4. The colonial term used to identify Yoruba diaspora bodies in Cuba.

5. Michael Atwood-Mason $(2002,91,94)$ attentively draws on Pierre Bourdieu's notion of habitus to show how Santería embodied rituals demonstrate the structuring of actions in Santería. In particular, he is concerned with how "symbolic work" is mapped onto bodies where the "source image (the item which is symbolically brought into play) is transferred and mapped onto the target situation (the situation or object symbolically described by the source)" (Atwood-Mason 2002, 102). Here, I follow Saba Mahmood (2005, 136) who critiques Bourdieu's emphasis on the unconscious reproduction of society, which, she argues, ignores the learned processes of self-fashioning. This move, I suggest, shifts habitus from a mind/body and subject/object binary to processes of forming.

6. Santería experiences are often presumed to be readily identifiable within our normatized ethnographic frameworks, but this forms part of what Kristina Wirtz (2007) identifies as an "epistemological ethnocentrism" inherited by discursive categories. See also Palmié 2010, 89.

7. Talal Asad's comments are taken from the question and answer section of a transcribed talk given by Jacques Derrida in 1997 in Paris, France, during a workshop entitled "Religion and Media." The proceedings from the workshop were published in de Vries and Weber (2001).

8. See, for example, Todd R. Ochoa's (2007, 487) critique of Hegelian negation in mediation.

9. Martin Holbraad (2008) similarly suggests that anthropologists shift modes of understanding truth by drawing from "native" ontologies in what he calls "ontography."

10. Interview with the author, May 13, 2006, Matanzas, Cuba.

11. Alfredo Calvo Cano was raised by his maternal grandmother, Lilita, who, as he indicated, was Monserrate Gonzalez's granddaughter. See also, Ferrer Castro and Acosta Alegre $(2006,45)$, who also interviewed Alfredo Calvo Cano.

12. There is a discrepancy on who initiated Fermina Gómez. Armando Ferrer Castro and Mayda Acosta Alegre $(2006,35)$ agree with John Mason $(1996,26)$ that it was a priest of Ochún. The former state only "ño José," while Mason gives the name "Kudaasi." David H. Brown (2003, 329), was told Gómez was initiated by "José Pata de Palo" (José Wooden Leg), a priest of Eleguá, named "Ño Cordá-isí."

13. Lydia Cabrera (1970, 81, 230; my translation) defines "Bi" as "born, engender, or alive" and describes "Ocha Bi" as the religious name for a priest of Yemayá.

14. In partial seatings, practitioners receive "head and feet": the Warriors (the feet) and their tutelary Orisha (the head).

15. Jacqueline Copeland-Carson $(2004,149)$ also uses habitus to understand how African ancestors in African diaspora bodily practices inform individual actions, but like AtwoodMason (2002), situates the unconscious as central to formations of agency and embodiment.

16. La Escalera is described as the first racial genocide in Cuban history (Barcia 2008, 45). More than four hundred Africans and free people of color were expelled from Cuba, initiating the first large-scale return migration to Africa (Nuñez Jimenez 1998, 56).

17. Also translated, by Charles Lam Markmann, as "the fact of blackness" (Fanon 1967).

\section{REFERENCES}

Armstrong, Robert Plant

1981 The Powers of Presence: Consciousness, Myth, and Affecting Presence. Philadelphia: University of Pennsylvania Press. 
Atwood-Mason, Michael

2002 Living Santería: Rituals and Experiences in an Afro-Cuban Religion. Washington, DC: Smithsonian.

Barcia, Manuel

2008 Seeds of Insurrection: Domination and Resistance on Western Cuban Plantations, 1808 1848. Baton Rouge: Louisiana State University Press.

Barrington Edmonds, Ennis, and Michelle A. Gonzalez

2010 Caribbean Religious History: An Introduction. New York: NYU Press.

Bolívar-Aróstegui, Natalia

1990 Los Orishas en Cuba. La Habana: Ediciones Unión.

Bordo, Susan

1998 "Bringing Body to Theory." In Body and Flesh: A Philosophical Reader, edited by Donn Welton, 84-97. Oxford: Blackwell.

Brandon, George

1997 Santería from Africa to the New World: The Dead Sell Memories. Bloomington: Indiana University Press.

Brenneis, Donald

2005 “Afterword: Sense, Sentiment, and Sociality." Etnofoor 18, no. 1: 142-49.

Brown, David H.

2003 Santería Enthroned: Art, Ritual, and Innovation in an Afro-Cuban Religion. Chicago: University of Chicago Press.

Brown, Jacqueline Nassy

2005 Dropping Anchor, Setting Sail: Geographies of Race in Black Liverpool. Princeton, N.J.: Princeton University Press.

Cabrera, Lydia

1968 El Monte. Miami: Rema Press.

1970 Anagó: Vocabulario Lucumi (El Yoruba Que Se Habla En Cuba). Miami, Fla.: Colleción Chicherekú Ediciones Universal.

Canizares, Raul

(1993) 2002 Santería Cubana: El Sendero de la Noche. Mexico, D.F.: Lasser Press Mexicana.

Clark, Mary Ann

2007 Santería: Correcting the Myths and Uncovering the Realities of a Growing Religion. Westport, Conn.: Greenwood.

Clarke, Kamari Maxine

2004 Mapping Yorùbá Networks: Power and Agency in the Making of Transnational Communities. Durham, N.C.: Duke University Press.

Copeland-Carson, Jacqueline

2004 Creating Africa in America: Translocal Identity in an Emerging World City. Philadelphia: University of Pennsylvania Press.

Cros Sandoval, Mercedes

2008 "Santería in the Twenty-First Century." In Orisà Devotion as World Religion: The Globalization of Yoruba Religious Culture, edited by Jacob K. Olupona and Terry Rey, 355-71. Madison: University of Wisconsin Press.

Csordas, Thomas. J.

1999 "Embodiment and Cultural Phenomenology." In Perspectives on Embodiment: The Intersections of Nature and Culture, edited by Gail Weiss and Honi Fern Haber, 143-62. London: Routledge.

2009 "Introduction: Modalities of Transnational Transcendence." In Transnational Transcendence: Essays on Religion and Globalization, edited by Thomas Csordas, 130. Berkeley: University of California Press.

2011 "Embodiment as a Paradigm for Anthropology." Ethos 18, no. 1: 5-47. http:// dx.doi.org/10.1525/eth.1990.18.1.02a00010. 
Daniel, Yvonne

2005 Dancing Wisdom: Embodied Knowledge in Haitian Vodu, Cuban Yoruba, and Bahian Candomblé. Urbana: University of Illinois Press.

de la Fuente, Alejandro

2001 A Nation for All: Race, Inequality and Politics in Twentieth-Century Cuba. Chapel Hill: University of North Carolina Press.

de la Torre, Miguel A.

2004 Santería: The Beliefs and Rituals of a Growing Religion in America. Grand Rapids, Mich.: Eerdmans.

Derrida, Jacques

2001 “Above All, No Journalists!" In Religion and Media, edited by Hent de Vries and Samuel Weber, 56-93. Stanford, Calif.: Stanford University Press.

de Vries, Hent, and Samuel Weber, eds.

2001 Religion and Media. Stanford, Calif.: Stanford University Press.

Diaconu, Mădălina

2002 “The Rebellion of the 'Lower' Senses: A Phenomenological Aesthetics of Touch, Smell, and Taste." In Essays in Celebration of the Founding of the Organization of the Phenomenological Organizations, edited by Cheung Chan-Fai, Ivan Chvatik, Ion Copoeru, Lester Embree, Julia Iribarne, and Hans Rainer Sepp. www.o-p-o.net.

2006 "Reflections on an Aesthetics of Touch, Smell and Taste." Contemporary Aesthetics Engelke, Mathew 4. www.contemporaryaesthetics.org.

2010 "Religion and the Media Turn: A Review Essay." American Ethnologist 37, no. 2: 371-79. http://dx.doi.org/10.1111/j.1548-1425.2010.01261.x.

2011 "Response to Charles Hirschkind: Religion and Transduction." Social Anthropology 19, no. 1: 97-1-2. http://dx.doi.org/10.1111/j.1469-8676.2010.00140_2.x.

Falola, Toyin, and Ann Genova, eds.

2005 Orisa: Yoruba Gods and Spiritual Identity in Africa and the Diaspora. Trenton, N.J.: Africa World Press.

Fanon, Frantz

1967 Black Skin, White Masks. Translated by Charles Lam Markmann. New York: Grove.

Feraudy Espino, Heriberto

2002 Irna: Un encuentro con la santería, el espiritismo y el Palo Monte. Cristo Rey, Santo Domingo: Editora Manati.

Fernandez Olmos, Margarite, and Lizabeth Paravisini-Gebert

1997 Sacred Possessions: Vodou, Santería, Obeah, and the Caribbean. New Brunswick, N.J.: Rutgers University Press.

Ferrer Castro, Armando, and Mayda Acosta Alegre

2006 Fermina Gómez y la casa olvidad de Olókun. Caracas, Venezuela: Fundación Editorial el perro y la rana.

Fontañez, Jovita

2006 "Folk Healing Traditions." In Latinas in the United States: A Historical Encyclopedia, edited by Vicki l. Ruiz and Virginia Sánchez Korrol, 266-70. Bloomington: Indiana University Press.

Guerts, Kathryn

2003 Culture and the Senses: Bodily Ways of Knowing in an African Community. Berkeley:

Guridy, Frank University of California Press.

2009 "Feeling Diaspora in Harlem and Havana." Social Text 27, no. 1 (98): 115-40. http: / /dx.doi.org/10.1215/01642472-2008-019.

Herskovits, Melville J.

1941 The Myth of the Negro Past. Boston: Beacon. 
Hesse, Barnor

1997 “It's Your World: Discrepant M/Multiculturalisms." Social Identities 3, no. 3: 375-94. http://dx.doi.org/10.1080/13504639751961.

Hirschkind, Charles

2006 The Ethical Soundscape: Cassette Sermons and Islamic Counterpublics. Columbia: Columbia University Press.

2011 “Media, Mediation, Religion.” Social Anthropology 19, no. 1: 90-97. http:// dx.doi.org/10.1111/j.1469-8676.2010.00140_1.x.

Holbraad, Martin

2008 "Definitive Evidence, from Cuban Gods." Journal of the Royal Anthropological Institute 14, no. S1: S93-S109. http://dx.doi.org/10.1111/j.1467-9655. 2008.00495.x.

Howes, David

1990 "Controlling Textuality: A Call for a Return to the Senses." Anthropologica 32, no. 1: 55-73. http://dx.doi.org/10.2307/25605558.

2003 Sensual Relations: Engaging the Senses in Culture and Social Theory. Ann Arbor: Jackson, Michael University of Michigan Press.

1983 "Knowledge of the Body." Man, n.s., 18, no. 2: 327-45. http://dx.doi.org/ 10.2307/2801438.

1989 “Thinking through the Body: An Essay on Understanding Metaphor.” Social Analysis, no. 14: 127-49.

Jobs, Sebastian, and Gesa Mackenthun

2011 Embodiments of Cultural Encounters. Münster, Germany: Waxmann.

Johnson, Paul C.

2002 Secrets, Gossip and Gods: The Transformation of Brazilian Candomblé. New York: Oxford University Press.

Kipfer, Stefan

2007 "Fanon and Space: Colonization, Urbanization, and Liberation from the Colonial to the Global City." Environment and Planning D: Society and Space 25, no. 4: 70126. http://dx.doi.org/10.1068/dkipfer.

Lingis, Alphonso

2005 Body Transformations: Evolutionisms and Atavisms in Culture. New York: Taylor and Francis.

Mahmood, Saba

2005 Politics of Piety: The Islamic Revival and the Feminist Subject. Princeton, N.J.: Princeton University Press.

Mann, Kristin, and Edna G. Bay, eds.

2001 Thinking the African Diaspora: The Making of a Black Atlantic World in the Bight of Benin and Brazil. New York: Taylor and Francis.

Mascia-Lees, Frances E.

2011 A Companion to the Anthropology of the Body and Embodiment. New York: WileyBlackwell. http://dx.doi.org/10.1002/9781444340488.

Mason, John

1996 Olóokun: Owner of Rivers and Seas. Brooklyn, N.Y.: Yoruba Theological Archministry.

Matory, James Lorand

2005 Black Atlantic Religion: Tradition, Transnationlaism and Matriarchy in the AfroBrazilian Condomblé. Princeton, N.J.: Princeton University Press.

2009 "The Many Who Dance in Me: Afro-Atlantic Ontology and the Problem with 'Transnationalism."' In Transnational Transcendence: Essays on Religion and Globalization, edited by Thomas Csordas, 231-62. Berkeley: University of California Press. 
Mauss, Marcel

(1935) 1992 "Techniques of the Body." In Incorporations, edited by Jonathan Crary and Sanford Kwinter, 455-77. New York: Zone.

Mazzarella, William

2004 “Culture, Globalization, Mediation.” Annual Review of Anthropology 33:345-67. http: / /dx.doi.org/10.1146/annurev.anthro.33.070203.143809.

Merleau-Ponty, Maurice

1964 The Primacy of Perception: And Other Essays on Phenomenological Psychology, the Philosophy of Art, History and Politics. Evanston, Ill.: Northwestern University Press.

Meyer, Brigit, ed.

2009 Aesthetic Formations: Media, Religion, and the Senses. New York: Palgrave Macmillan.

Miller, Ivor

2009 Voices of the Leopard: African Secret Societies and Cuba. Jackson: University of Mississippi Press.

Moliner Castañeda, Israel

2002 Los Cabildos Afrocubanos en Matanzas. Matanzas, Cuba: Ediciones Matanzas.

Murphy, Joseph

1994 Working the Spirit: Ceremonies of the African Diaspora. Boston: Beacon.

Murphy, Joseph, and Mei-Mei Sanford, eds.

2001 Osun Across the Waters: The Yoruba Goddess in Africa and the Americas. Bloomington: Indiana University Press.

Noland, Carrie

2009 Agency and Embodiment: Performing Gestures/Producing Culture. Cambridge, Mass.: Harvard University Press.

Nuñez Jimenez, Antonio

1998 Los Esclavos Negros. La Havana: Ediciones Mec Graphic.

Ochoa, Todd R.

2007 "Versions of the Dead: Kalunga, Cuban-Kongo Materiality, and Ethnography." Cultural Anthropology 22, no. 4: 473-500. http://dx.doi.org/10.1525/can. 2007.22.4.473.

2010 Society of the Dead: Quita Manaquita and Palo Praise in Cuba. Berkeley: University of California Press.

Olupona, Jacob K., and Terry Rey, eds.

2008 Orisà Devotion as World Religion: The Globalization of Yorùbá Religious Culture. Madison: University of Wisconsin Press.

Ortiz, Fernando

1987 Contrapunteo cubano del tabaco y el azúcar. Madrid: Ediciones Cátedra.

Otero, Solimar

2010 Afro-Cuban Diasporas in the Atlantic World. Rochester: University of Rochester Press.

Palmié, Stephan

1995 “Against Syncretism: 'Africanizing' and 'Cubanizing' Discourses in North American Orisa Worship.” In Counterworks: Managing the Diversity of Knowledge, edited by Richard Fardon, 73-104. New York: Routledge.

2002 Wizards and Scientists: Explorations in Afro-Cuban Modernity and Tradition. Durham, N.C.: Duke University Press.

2010 “Now You See It, Now You Don’t: Santería, Anthropology, and the Semiotics of 'Belief' in Santiago de Cuba." New West Indian Guide 84, no. 1: 87-96.

2013 The Cooking of History: How Not to Study Afro-Cuban Religion. Chicago: University

Routon, Kenneth of Chicago Press.

2008 "Conjuring the Past: Slavery and the Historical Imagination in Cuba." American 
Ethnologist 35, no. 4: 632-49. http://dx.doi.org/10.1111/j.1548-1425.2008. 00102.x.

2010 Hidden Powers of the State in the Cuban Imagination. Gainesville: University of Florida Press.

Sansi-Roca, Roger

2005 "The Hidden Life of Stones: Historicity, Materiality and the Value of Candomble Objects in Bahia.” Journal of Material Culture 10, no. 2: 139-56. http://dx. doi.org/10.1177/1359183505053072.

Scott, Darieck

2010 Extravagant Abjection: Blackness, Power, and Sexuality in the African American Literary Imagination. New York: NYU Press.

Sekyi-Otu, Ato

1997 Fanon's Dialectic of Experience. Cambridge, Mass.: Harvard University Press.

Seremetakis, C. Nadia

1993 "The Memory of the Senses: Historical Perception, Commensal Exchange and Modernity." Visual Anthropology Review 9, no. 2: 2-18.http://dx.doi.org/10. 1525/var. 1993.9.2.2.

Sheets-Johnstone, Maxine

1999 The Primacy of Movement. Philadelphia: John Benjamin's Publishing.

Sklar, Deidre

1994 "Can Bodylore Be Brought to Its Senses?" Journal of American Folklore 107, no.

Taussig, Michael 423: 9-22. http://dx.doi.org/10.2307/541070.

1993 Mimesis and Alterity: A Particular History of the Senses. New York: Psychology Press.

Thomas, Helen, and Jamilah Ahmed, eds.

2004 Cultural Bodies: Ethnography and Theory. Malden, Mass.: Blackwell.

van de Port, Mattijs

2006 "Visualizing the Sacred: Video Technology, 'Televisual' Style, and the Religious Imagination in Bahian Candomblé.” American Ethnologist 33, no. 3: 44461. http://dx.doi.org/10.1525/ae.2006.33.3.444.

van Ede, Yolanda

2009 "Sensuous Anthropology: Sense and Sensibility and the Rehabilitation of Skill." Anthropological Notebooks 15, no. 2: 61-75.

Velez, Maria Teresa

2000 Drumming for the Gods: The Life and Times of Felipe García Villamil, Santero, Palero, and Abakuá. Philadelphia: Temple University Press.

Wirtz, Kristina

2007 Ritual, Discourse, and Community in Cuban Santería: Speaking a Sacred World. Gainesville: University of Florida Press. 